\section{THE MELBOURNE MEETING OF THE AUSTRALASIAN ASSOCIATION.}

THE Australasian Association for the Advancement of Science met at Melbourne, under the presidency of Prof. T. W. E. David, F.R.S., on January 7-14. The meeting proved most successful. There was a large and representative gathering of members from all the Australian States and New Zealand. Owing to the approaching visit of the British Association, it was decided to postpone the Hobart meeting, which in the ordinary course of events would have been fixed for 1915, until the beginning of I916, and the cordial invitation, which the New Zealand delegates brought, that the succeeding meeting be in Wellington, was accepted.

The subject of the presidential address was "The Australian Climate, Past and Present," but before passing to it, Prof. David spoke of the interest the Federal Government had shown in scientific worls relating to the Commonwealth. Its action in organising the recent scientific expedition to the northern territory, under Prof. Baldwin Spencer, and in arranging for his presence there for the last year, had commended itself both to the general public and to workers in science. The reports already published showed that the northern territory had far greater possibilities than most people had imagined, in regard both to its pastoral and mining features. The appointment of a man of science, Prof. Gilruth, to the important position of administrator was a step for which the association was grateful to the Government.

Papua also had not been neglected, and the mission of Mr. Carne to that country had been most successful. Among other things, he had located an extensive belt of oil-bearing sandstones, which he believed to be an extension of the great Burmese oil-belt, which ran through Sumatra, Borneo, and Java, to Timor, and thence to New Guinea. The oil-belt was full of possibilities, and he thought there was no more fascinating field for exploration than this island.

Dealing with the Australian climate, Prof. David spoke of the importance of the scientific observations of the Antarctic expeditions, especially those of Capt. Scott and Dr. Mawson. The meteorological data, communicated by wireless telegraphy from Macquarie Island by members of Mawson's expedition, showed most distinctly the association between the weather conditions of Australia and those of the subantarctic. It was to be hoped that in the near future some joint arrangement would be made between the Governments of Australia and New Zealand, providing for the continued upkeep of the station on that island.

From the evidence he had collected, he believed.that the reason for the great climatic and biological differences between the north and south polar regions is mainly geographical; that it depends on the present distribution of land and water, and on the modifications which they introduce into the circulations of air and water in either hemisphere. The existence of the large continent of Antarctica, with an average elevation of about $6000 \mathrm{ft}$., acts as a great refrigerator in the southern hemisphere, and causes extremes, which otherwise would not exist, between the south polar and equatorial temperatures. This factor tends to increase the rapidity of air circulation in the southern hemisphere. It accounts for the periodic fierce outrushes of blizzard winds, which accompany the development of the Antarctic low-pressures, and often profoundly affect Australian weather conditions.

On the other hand, the absence of land in the north polar regions, and the presence of open water in the summer, cause the temperature in those regions to be much higher at that season in the Arctic than in the Antarctic.

In the course of his address, Prof. David made particular reference to the need for further development of the Department of Meteorology in Australia, and he stated that there was every prospect of the Federal Government malking the Australian Solar Physics Observatory an accomplished fact in the near future.

A noteworthy feature of the meeting was a lecture on the northern territory and its aborigines, delivered in the Melbourne Town Hall, by Prof. Baldwin Spencer, who had just returned after a year's absence in the territory on a special mission from the Federal Government. The Governor-General and the Prime Minister were present, and the large hall was crowded long before the hour at which the lecture commenced.

Prof. Spencer began by a reference to the vastness of this part of Australia. It was four and a half times as large as Great Britain, but its population, excluding the aborigines, was less than 4000 ; and of the aborigines he did not think there were more than 40,000. The Commonwealth Government now had control of this region, and it had organised a series of important departments in which work of a valuable character was already being performed. It was necessary to remember that for forty years practically very little had been done in the territory. Now they had in their administrator a strong, straight, and fearless man, who had quickly won the complete trust and confidence of everyone working under him. The climate was undoubtedly trying, particularly in the wet season, which extends from March until September. But inland, on the "downs" country, it is infinitely better than on the coastal fringe. He believed that this cool winter climate would make a very great difference in the opening up, at any rate, of these inland regions, and the existence of these cooler temperatures at certain seasons of the year made the country differ from other tropical regions where such changed conditions were unknown.

Dealing with the natives, he was able to show the audience by kinematograph views and phonograph rccords some of the results of his investigations. A stay of about two months had been made on a station in the Alligator River district, and this time devoted wholly to acquiring information upon the habits, beliefs, and customs of the natives. He found these differed somewhat from those of the southern tribes.

A visit had also been paid to Melville Island, some forty miles from the mainland, which he reached in a small lugger from Port Darwin. The aborigines inhabiting that island vere of a better type than those on the mainland. He saw ceremonies performed which were entirely new to him, notably a weird performance in connection with the burial of a man. A small plot of ground having been cleared of vegetation, a number of fantastic grave-posts were placed upright in the ground on either side of the prepared spot. Some fifty natives lined up, after the fashion of soldiers, whilst four other men ran between and around the grave-posts, stamping with their feet, which action was supposed to drive the spirit of the departed into the ground. Other films depicted the islanders in the canoes, in which thev often negotiated the stretch of open ocean between the island and the mainland, forty miles across.

In his concluding remarks, Prof. Spencer said that the natives of the northern territory had certain attributes of a high character. Undoubtedly it was a great problem to know what to do with them; their entire lack of knowledge of agricultural methods rendered the problem all the more difficult of solution. $\mathrm{He}$ hoped very shortly to lay a scheme before the NO. 2266, VOL. 9I] 
Government whereby they would be in great reserves, protected from contaminating influences, and led to a higher and better life.

Many papers were communicated to the various sections, but limitations of space will not permit us to describe them. The presidents of sections and the subjects of their addresses, where this information has reached us, were as follows:-A, "The Relation between Pure and Applied Mathematics," Prof. H. S. Carslaw; B, Prof. C. Fawsitt; C, "The Evolution of the Physiographic Features of South Australia," Mr. W. Howchin; D, "The Present Aspect of Some Problems of Heredity," Prof. H. B. Kirk; F, Practical Aspects of Anthropology," Dr. W. Ramsay Smith; G, Observations regarding the Production and Distribution of Consumable Wealth and Economic Capital, with an Inquiry into the Probable Effect of Arbitrary Regulations of Minimum-wage Standards upon the Cost of Living; H, "A Review of the Existing Conditions of the Twin Professions of Engineering and Architecture in Australia "; K, "The Relation of Fertilisers to Soil Fertility," Mr. F. B. Guthrie.

A large number of reports received the approval of the general council of the association, but we can only refer to a few of them.

It was approved that a committee be appointed with instructions $(a)$ to bring under the notice of the Federal Government the desirability of its providing for a re-determination of the difference of the longitudes of Singapore and Darwin, and of the differences of longitude of the Australian observatories from each other; $(b)$ to communicate with the Indian Government with respect to the possibility of re-determining the difference between Madras and Singapore.

Prof. David brought up a recommendation that in view of the already proved importance to pure science, to weather forecasting, and to shipping, of the meteorological station and wireless installation at Macquarie Island, a committee be appointed with power to add to its number to take all steps necessary to maintain the station on a permanent basis. Macquarie Island is situated just half-way (a) between Australia and New Zealand, and $(b)$ between both those countries and the Antarctic continent.

In the reports presented to the Glacial Research Committee, Prof. W. G. Woolnough records an extensive area of Permo-Carboniferous glacial beds discovered by him on the Manning River and the Macleay River, some $5_{50}$ to 250 miles north of Sydney. The Boulder beds are associated with marine strata, and near Tane, on the Manning River, the more southern locality, the boulders are embedded in limestone. This occurrence is compared with the marine glacial beds of Jervis Bay, New South Wales. Mr. $R$. Speight summarises the results of recent investigations into the glaciation of New Zealand.

It was resolved that in view of the rapid decadence and disappearance of the Australian aborigines it is urgent that, in the interests of science, further records and collections, illustrative of the beliefs, customs, and manner of life of the aborigines should be made for public preservation, more especially with reference to Queensland and Western Australia. It was resolved also to take such steps as may be deemed necessary to enforce the existing law with regard to the exploration of anthropological material, and further to prevent the indiscriminate exportation of other anthropological and ethnological specimens from any part of the Commonwealth.

A committee was appointed to consider the best means of securing the efficient teaching of English pronunciation in Australasian universities, training colleges, and schools.

A committee appointed at the Sydney meeting, r9II, brought up a progress report on the steps to be taken with the view to the compilation of a list of the scientific serial periodical literature, both in public and private possession, in each of the principal cities of Australia.

\section{REPORTS OF THE SMITHSONIAN INSTITUTION. ${ }^{1}$}

THE report of the secretary of the Smithsonian Institution for the year ending June 30 , 1912, has been received from Washington. The general report reviews the affairs of the institution proper, with brief paragraphs relating to its several branches. The numerous appendices provide, in addition, detailed reports of the work-placed by Congress under the direction of the Board of Regents of the Smithsonian Institution-in the United States National Museum, the Bureau of American Ethnology, the National Zoological Park, and some four or five other organisations.

It is worthy of note that the total permanent fund of the institution amounts to $197,384 l$. The income for the year was $21,432 l$., of which $11,675 l$. Was interest on the permanent fund. The disbursements for the year amounted to $2 \mathrm{r}, 107 \mathrm{l}$. More than this, the institution was responsible to Congress for the spending of the grants to the scientific organisations named above, and these reached a total of $148,400 l$.

The report of the Board of Regents consists of two main divisions : first, the annual report of the secretary, giving an account of the operations and conditions of the institution for the year ending June 30 , I9II, and following the same general lines as the more recent report by the secretary dealt with above; and, secondly, the general appendix, comprising a selection of miscellaneous memoirs of interest, chiefiy belonging to the year IgIr, likely to be useful to men of science and others.

Among the original contributions to the general appendix is one by Mr. F. Alex. McDermott, of Washington, on recent advances in our knowledge of the production of light by living organisms; others are by Mr. N. C. Macnamara, on organic evolution : Darwinian and De Vriesian; by Mr. Paul C. Standley, on some useful native plants of New Mexico; and by Mr. William R. Maxon, on the tree ferns of North America.

Prof. A. M. Tozzer, of Harvard University, in a paper reprinted from the Proceedings of the American Antiquarian Society (Worcester, Mass., April, I9II), gives much interesting information concerning the value of ancient Mexican manuscripts in the study of the development of writing. These manuscripts, and those of Central America, constitute important examples of primitive ideas regarding art and illustration, as well as data of great ethnological value. The countries of Mexico and Central America are the only fields of the New World where any appreciable data on prehistoric life other than monuments, implements, and other objects are found. The manuscripts of Mexico are divided by Prof. Tozzer into two classes-those written before the advent of the Spaniards, and those written during early Spanish occupation.

Prof. Tozzer describes the manuscripts under discussion, and follows the development of writing from the period of reminders or mnemonics, to actual pictures, from them to a symbolistic and conventional

1 Report of the Secretary of the Smithsonian Institution for the Year ending June 30, 1912. (Washington: Government Printing Office, 1912.) Annual Report of the Board of Regents of the Smithsonian Institution showing the Operations, Expenditures, and Condition of the Institution for the Year ending June 30, IgIr. (Washington: Government Printing Office, rgr2.) 